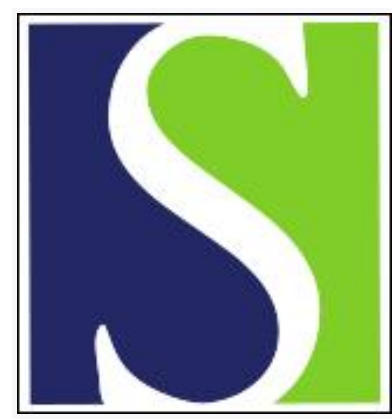

Scand J Work Environ Health 2004;30(1):21-29

https://doi.org/10.5271/sjweh.761

Issue date: Feb 2004

Effects on the peripheral nervous system of tunnel workers exposed to acrylamide and $\boldsymbol{N}$-methylolacrylamide

by Kjuus H, Goffeng LO, Heier MS, Sjöholm H, Øvrebø S, Skaug V, Paulsson B, Törnqvist M, Brudal S

Affiliation: Department of Occupational Medicine, National Institute of Occupational Health, Pb 8149 Dep N-0033 Oslo, Norway. Helge.Kjuus@stami.no

Refers to the following texts of the Journal: $2001 ; 27(4): 219-226$ 2001;27(4):217-218

The following articles refer to this text: 2004;30(3):253; 2004;30(3):253-254; 2011;37(2):136-146

Key terms: acrylamide; exposure; grouting agent; hemoglobin adducts; N-methylolacrylamide; nerve conduction velocity; peripheral nervous system; reversibility; symptom; tunnel worker

This article in PubMed: www.ncbi.nlm.nih.gov/pubmed/15018025

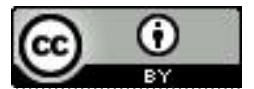




\title{
Effects on the peripheral nervous system of tunnel workers exposed to acrylamide and $N$-methylolacrylamide
}

\author{
by Helge Kjuus, PhD, ${ }^{1}$ Lars Ole Goffeng, PsyD, ${ }^{1}$ Mona Skard Heier, PhD, ${ }^{2}$ Hans Sjöholm, PhD, ${ }^{2}$ Steinar \\ Øvrebø, PhD, ${ }^{3}$ Vidar Skaug, MD, ${ }^{3}$ Birgit Paulsson, PhD, ${ }^{4}$ Margareta Törnqvist, PhD, ${ }^{4}$ Stein Brudal, MD ${ }^{5}$
}

\begin{abstract}
Kjuus H, Goffeng LO, Heier MS, Sjöholm H, Øvrebø S, Skaug V, Paulsson B, Törnqvist M, Brudal S. Effects on the peripheral nervous system of tunnel workers exposed to acrylamide and $\mathrm{N}$-methylolacrylamide. Scand $\mathrm{J}$ Work Environ Health 2004;30(1):21-29.
\end{abstract}

\begin{abstract}
Objectives This study evaluates the possible toxic effects on the peripheral nervous system of tunnel workers exposed to acrylamide and $\mathrm{N}$-methylolacrylamide during grouting work.

Methods Symptoms and nerve conduction velocities (NCV) were recorded for 24 tunnel workers 4 and 16 months after the cessation of exposure during grouting operations. Fifty tunnel workers not involved in grouting operations served as referents. Exposure was assessed by questionnaires, qualitative exposure indices, and measurements of hemoglobin adducts after the cessation of exposure.

Results The exposed workers reported a higher prevalence of symptoms during grouting work than they did in an examination 16 months later. A statistically significant reduction in the mean sensory NCV of the ulnar nerve was observed 4 months postexposure when compared with the values of the reference group (52.3 versus $58.9 \mathrm{~m} / \mathrm{s}, \mathrm{P}=0.001$ ), and the mean ulnar distal delay was prolonged ( 3.1 versus $2.5 \mathrm{~ms}, \mathrm{P}=0.001$ ). Both measures were significantly improved when measured 1 year later. Exposure-related improvements were observed from 4 to 16 months postexposure for both the median (motor and sensory NCV and F-response) and ulnar (sensory NCV, Fresponse) nerves. A significant reversible reduction in the mean sensory amplitude of the median nerve was also observed, while the mean sensory amplitude of the sural nerve was significantly reduced after 16 months.

Conclusions The results indicate demyelinating and axonal changes in peripheral nerves of tunnel workers in relation to exposure to $\mathrm{N}$-methylolacrylamide and acrylamide during grouting operations. The changes were slight, mostly subclinical, and most of the effects were reversible, with normalization after 1 year.
\end{abstract}

Key terms grouting agents, hemoglobin adducts, nerve conduction velocity, reversibility, symptoms.

During 1995-1997, a 14-kilometer railway tunnel was constructed between the city of Oslo and the new Gardermoen Airport. Due to nonsolid rock structures in the tunnel area, water leakage into the tunnel became a problem. From September 1995 to August 1997, 340 000 kilograms of an acrylamide-based grouting agent were used for injection in the tunnel. From another tunnel project in Hallandsås in Sweden (1), reports of adverse effects from the use of the same grouting agent appeared in the Norwegian press in the autumn of 1997. Shortly afterwards, several Norwegian tunnel workers also complained of symptoms compatible with effects of acrylamide exposure (2).
Monomeric acrylamide is neurotoxic, is probably carcinogenic to humans, and may have reproductive effects on animals $(3,4)$. Occupational exposure to acrylamide may present a hazard for workers, primarily through skin irritation and effects on the nervous system, and may have a potential cancer risk. Due to these toxic properties of acrylamide, several other grouts have been developed. Among them, one is based on the less toxic $N$-methylolacrylamide (NMA), to which the studied Norwegian workers were exposed.

We examined the relationship between exposure to the NMA-containing grouting solution and the health effects on 24 tunnel workers and focused on the possible

1 Department of Occupational Medicine, National Institute of Occupational Health, Oslo, Norway.

2 Department of Clinical Neurophysiology, Ullevål University Hospital, Oslo, Norway.

3 Department of Toxicology, National Institute of Occupational Health, Oslo, Norway.

4 Department of Environmental Chemistry, Stockholm University, Sweden.

5 Alna HMS Centre, Oslo, Norway.

Reprint requests to: Dr Helge Kjuus, Department of Occupational Medicine, National Institute of Occupational Health, Pb 8149 Dep N-0033 Oslo, Norway. [E-mail: Helge.Kjuus@stami.no] 
acute effects on the nervous system. The possible reversibility of the effects was studied by re-examining the group 1 year later, with measurements of nerve conduction velocities, amplitudes, and F-latencies. The results were correlated to the estimated degree of exposure.

\section{Participants and methods}

\section{Grouting agent and exposure conditions}

NMA is produced from acrylamide and formaldehyde, in aqueous solution: acrylamide + formaldehyde $\leftrightarrow$ NMA. The reaction is in favor of NMA. Polymerization may be considerably delayed at low temperatures. Consequently, the grout will not adhere perfectly to the fissures and may leak out again. Thus exposure to the mixed, but not yet polymerized, product may occur.

The used grout was based on two solutions. Solution 1 consisted of 26-29\% NMA, 0.02-0.03\% methylene-bisacrylamide, $12-17 \%$ methylic diesters (catalyst), $0.9 \%$ formaldehyde, and water. Solution 2 was comprised of sodium silicate, sodium persulfate, and water. According to the declaration of content, solution 1 also contained up to $1.5 \%$ acrylamide. Revised information from the producer stated that there was $2.5-5 \%$ (average $4 \%$ ) acrylamide in solution 1. In Sweden, analyses of different batches from Hallandsås showed acrylamide concentrations between 4.0\% and 5.4\% and NMA concentrations between $29 \%$ and $31 \%$ (1). When ready-mixed, the grout consisted of 3.75 parts water, 0.125 parts solution 1 , and 0.125 parts solution 2. Both solutions were emptied into an open mixing vessel and manually stirred. The mixture was then pumped through an injector gun in a closed system into drill holes in the rock. After injection, the equipment was cleaned and sometimes repaired by the operators. The main exposure occurred during the mixing and pumping of the grouting solution and during the injection of the grouting solution into the drill holes in the tunnel wall. The grouting solution frequently splashed back towards the worker. In addition, workers often reported "showers" of leaking water, contaminated with acrylamide, from the tunnel roof.

\section{Participants}

The study base consisted of 73 workers who had taken part in tunnel work during the grouting period and were thus potentially exposed to NMA grout. Due to the focus on possible acrylamide exposure, these 73 workers participated in a health examination at the occupational health unit (OH survey) during October 1997-January 1998. Using the survey and meetings with groups of workers and safety representatives, we identified the 25 workers with the highest exposure to acrylamide-containing grout. All the workers gave their written informed consent to participate in the study. Persons with known neurological disease, diabetes mellitus, or known alcohol or drug abuse were not eligible for the study. One person was found to have diabetes and was excluded. Fifty tunnel workers not exposed to NMA grouts were selected as referents.

The 24 exposed workers had been engaged in tunnel construction or other construction work for 19.3 (SD 7.8) years, the corresponding time being $20.4(\mathrm{SD}=10.2)$ years for the referents. The distribution of age, life-style factors (smoking, alcohol consumption), and other relevant exposure factors are presented in table 1. No major differences in exposure to these factors were observed between the two groups.

\section{Exposure assessment}

All 24 workers had taken active part in the injection of grouting agents for an average of 19.4 (range 8.1-24.1) months. Of the 24, 17 had performed injections for more than 18 months. Altogether 20 reported direct skin contact with acrylamide grout, while all 24 claimed skin contact with tunnel water.

No measurements of acrylamide or NMA had been taken in the work environment during the injection work. The two available sources for quantitative exposure information were some measurements of acrylamide and NMA in tunnel water and measurements of hemoglobin adducts from acrylamide, analyzed in blood samples from the tunnel workers 2-5 months after the cessation of the injection work. Information on the amount of grout used per week in the separate parts of the tunnel was also available.

Table 1. Distribution of age, life-style factors (smoking, alcohol consumption), and other relevant exposure factors for the exposed and reference groups.

\begin{tabular}{|c|c|c|c|c|c|c|c|c|c|c|c|c|c|}
\hline \multirow[t]{2}{*}{ Group } & \multicolumn{3}{|c|}{ Age (years) } & \multicolumn{2}{|c|}{$\begin{array}{c}\text { Years in } \\
\text { construction work }\end{array}$} & \multicolumn{2}{|c|}{$\begin{array}{c}\text { Present } \\
\text { smokers (\%) }\end{array}$} & \multirow[t]{2}{*}{$\begin{array}{l}\text { Alcohol, } \\
\text { >5 l/year } \\
(\%)\end{array}$} & \multirow[t]{2}{*}{$\begin{array}{c}\text { Work with } \\
\text { solvents } \\
(\%)\end{array}$} & \multirow[t]{2}{*}{$\begin{array}{l}\text { Previous } \\
\text { lead ex- } \\
\text { posure (\%) }\end{array}$} & \multicolumn{2}{|c|}{$\begin{array}{l}\text { Exposure to } \\
\text { vibrating hand } \\
\text { tools }(\%)\end{array}$} & \multirow{2}{*}{$\begin{array}{c}\text { Exposure to } \\
\text { whole-body } \\
\text { vibration, } \\
(\%)\end{array}$} \\
\hline & Mean & SD & Range & Mean & SD & $\%$ & $\begin{array}{c}\text { Mean } \\
\text { number } \\
\text { of } \\
\text { cigarettes }\end{array}$ & & & & $\%$ & $\begin{array}{l}\text { Mean } \\
\text { number } \\
\text { of } \\
\text { years }\end{array}$ & \\
\hline Exposed $(\mathrm{N}=24)$ & 43.1 & 8.6 & $31-62$ & 19.3 & 7.8 & 45.8 & 12.8 & 33.3 & 47.8 & 9.5 & 100.0 & 6.0 & 34.8 \\
\hline Reference $(\mathrm{N}=50)$ & 43.9 & 9.6 & $23-60$ & 20.4 & 10.2 & 50.0 & 15.3 & 24.0 & $61.2^{a}$ & 16.0 & 91.9 a & 7.9 & 50.0 \\
\hline
\end{tabular}

${ }^{\text {a }} \mathrm{N}=49$. 


\section{Measurements of tunnel water}

Due to the technical and environmental problems with water leakage, the tunnel digging work came to a halt on 25 August 1997. Before this time, only a few sporadic measurements of acrylamide had been made in drain water from the tunnel. The highest concentrations were measured on 25 August, with $9654 \mu \mathrm{g} / \mathrm{l}$ for acrylamide and 16 $600 \mu \mathrm{g} / \mathrm{l}$ for NMA (5). During September, the average concentration of acrylamide was 100-110 $\mu \mathrm{g} / \mathrm{l}$, while during October 1997-April 1998 most of the measurements were below $50 \mu \mathrm{g} / \mathrm{l}$. However, in January 1998, during the injection of other grouting agents, several drill holes with unpolymerized grout were discovered. Very high concentrations of acrylamide were measured in the water dripping from these holes in the tunnel wall (up to 90600 $\mu \mathrm{g} / \mathrm{l})$.

\section{Analyses of hemoglobin adducts from acrylamide}

During October-December 1997, blood samples were obtained from 23 of the 24 tunnel workers and 3 referents. Red blood cells were separated from the plasma, and globin was precipitated and purified from the red blood cells (6). The samples were prepared, and adducts to $\mathrm{N}$-terminal valine in hemoglobin $(\mathrm{Hb})$ were analyzed by gas chromatography-mass spectrometry and mass spectrometry (GC-MS/MS) according to the $N$-alkyl Edman method (7), with modifications according to Bergmark et al (8)

\section{Qualitative exposure information}

Using information obtained from the questionnaires, we estimated the accumulated time for tunnel work for each worker (tunnel time, TT, in days) and the accumulated time for injection work (injection time, IT, in days) during the period September 1995-August 1997. On the basis of information about the amount of grout used in the different periods, the 2-year period was divided into a "low exposure period" (LEP) (September 1995-November 1996), a "high exposure period" (HEP) (December 1996-August 1997), and a "tunnel water period" (TWP) (September-October 1997. An exposure time index (ETI) was estimated as $(\mathrm{LEP} \times 2)+(\mathrm{HEP} \times 4)+$ (TWP $\times 0.5)$, on the basis of an arbitrarily chosen weighting of 2, 4, and 0.5 given to the three periods, respectively. From the questionnaires, we developed an intensity index, which was a sum measure based on the frequency of injection (often: 6, seldom: 2, never: 0), mixing operations (often: 2 , seldom: 1 , never: 0 ), cleaning operations (often: 2 , seldom: 1 , never: 0 ), the spilling of NMA on skin (3-0, according to 5 questions), skin contact (yes: 1, no: 0), and the inhalation of grout (yes: 1, no: 0 ). The intensity index was a sum score with the range $0-15$.

\section{Examinations}

The exposed participants were examined with the use of questionnaires and measurements of nerve conduction properties an average of 4 months after the injection work (4 months "postexposure"). They were re-examined 1 year later (16 months "postexposure"). The referents were examined using the same methods.

\section{Neurophysiological measurements}

Nerve stimulation and the recording of nerve and muscle action potentials were performed with bipolar surface electrodes according to established standardized procedures using a 4-channel "Dantec keypoint". Motor nerve conduction velocity, amplitude, and F-latency were measured in the right median, ulnar, peroneal, and posterior tibial nerves. Sensory nerve conduction velocities and amplitudes were measured in the right median and ulnar nerves using orthodromic stimulation of the palm and by recording $7 \mathrm{~cm}$ from the stimulation site at the volar side of the wrist. The sensory nerve conduction velocity and amplitude of the sural nerve were measured with antidromic stimulation approximately $10 \mathrm{~cm}$ proximal to the distal insertion of the achilles tendon with the recording electrode placed below the lateral malleolus. F-latencies were measured as the shortest latency from 20 successive optimal stimuli.

\section{Statistics}

The McNemar test for two related samples was used to test the difference between reported symptoms (dichotomous variables) during exposure and 16 months post-exposure. When comparing the difference between neurographic measures of the exposed and reference groups, we used the t-test for two unrelated samples. To test for changes in the neurographic measures from 16 to 24 months postexposure, we applied the t-test for two related samples. In addition, Spearman correlation coefficients were estimated to test the association between the semiquantitative exposure indices and the change (as the percentage) in the neurographic measurements from $4\left(\mathrm{~T}_{1}\right)$ to $16\left(\mathrm{~T}_{2}\right)$ months postexposure $\left(\mathrm{T}_{1}-\mathrm{T}_{2}\right)$. The level of statistical significance was set two-tailed at $\mathrm{P}<0.05$. The SPSS statistical package (SPSS Inc, Chicage, IL, USA) was applied using a personal computer.

\section{Results}

\section{Hemoglobin adducts}

Adducts from acrylamide were measured in 23 of the 24 workers (12 smokers and 11 nonsmokers) and in

Scand J Work Environ Health 2004, vol 30, no 1 
3 referents (1 nonsmoker and 2 smokers). Because of the limited number of referents, five samples from nonsmoking referents from two Swedish studies, analyzed on the same occasion as the samples from the present study, were added. The blood samples were collected 60-143 (mean 84) days after the end of the grouting injection work. The mean acrylamide adduct concentration was $156 \mathrm{pmol} / \mathrm{g} \mathrm{Hb}$ for the exposed group $(\mathrm{N}=23)$ and $63 \mathrm{pmol} / \mathrm{g} \mathrm{Hb}(\mathrm{N}=8)$ for the unexposed referents. Only two tunnel workers, one smoker and one nonsmoker, had a relatively high adduct increment in comparison with the reference levels, $890 \mathrm{pmol} / \mathrm{g} \mathrm{Hb}$ and 280 $\mathrm{pmol} / \mathrm{g} \mathrm{Hb}$, respectively. For these two workers, the samples were collected 60 and 70 days after the last use of acrylamide-containing grouts.

The background level of adducts from acrylamide and the contribution from tobacco smoking (9) imply that low occupational exposures to acrylamide are best assessed from nonsmokers.

The mean acrylamide adduct level of the 11 nonsmoking workers was 82 (range 33-85) pmol/g Hb (with one extreme value of $280 \mathrm{pmol} / \mathrm{g} \mathrm{Hb}$ ) compared with 33 (range 20-47) pmol/g Hb for the 6 nonsmoking referents $(\mathrm{P}<0.01)$. The smokers showed, as expected, higher average adduct levels for acrylamide, 225 (range 126-253) $\mathrm{pmol} / \mathrm{g} \mathrm{Hb}$ (with one extreme value of $890 \mathrm{pmol} / \mathrm{g} \mathrm{Hb}$ ) for the 12 exposed workers and 154 $\mathrm{pmol} / \mathrm{g} \mathrm{Hb}$ for the 2 referents.

\section{Symptoms}

Table 2 shows the reported symptom prevalence during the injection work and the corresponding figures reported in questionnaires 16 months postexposure. There was a lowered prevalence of reported paresthesia and of pain in the hands at the time of the follow-up examination, from $40.9 \%$ to $18.2 \%$ and from $23.8 \%$ to $9.5 \%$, respectively.

Table 2. Symptoms reported by 24 acrylamide-exposed tunnel workers in relation to the nervous system during the period of exposure to grouting work and 16 months after the exposure.

\begin{tabular}{|c|c|c|c|c|c|c|}
\hline \multirow[t]{3}{*}{ Symptom } & \multirow{3}{*}{$\begin{array}{c}\text { Total } \\
\text { number } \\
\text { of } \\
\text { workers }\end{array}$} & \multicolumn{5}{|c|}{ Workers experiencing symptoms } \\
\hline & & \multicolumn{2}{|c|}{$\begin{array}{l}\text { During } \\
\text { exposure }\end{array}$} & \multicolumn{2}{|c|}{$\begin{array}{c}\text { Post- } \\
\text { exposure }\end{array}$} & \multirow[t]{2}{*}{$\begin{array}{c}\text { P- } \\
\text { value }\end{array}$} \\
\hline & & $\mathrm{N}$ & $\%$ & $\mathrm{~N}$ & $\%$ & \\
\hline \multicolumn{7}{|l|}{ Hands } \\
\hline Paresthesia & 22 & 9 & 40.9 & 4 & 18.2 & 0.13 \\
\hline Pain & 21 & 5 & 23.8 & 2 & 9.5 & 0.45 \\
\hline Weakness & 24 & 3 & 12.5 & 4 & 16.7 & 1.00 \\
\hline \multicolumn{7}{|l|}{ Feet } \\
\hline Paresthesia & 22 & 6 & 27.3 & 5 & 22.7 & 1.00 \\
\hline Pain & 21 & 4 & 19.0 & 3 & 14.3 & 1.00 \\
\hline Cramps & 22 & 4 & 18.2 & 3 & 13.6 & 1.00 \\
\hline
\end{tabular}

a McNemar test, exact 2-tailed.
However, none of these differences were statistically significant. For the other symptoms, the prevalence of skin irritation and the peeling of skin on hands were reduced at the time of the follow-up examination $(35.0 \%$ versus $5.0 \%, \mathrm{P}=0.03$, and $34.8 \%$ versus $17.4 \%, \mathrm{P}=0.13$, respectively).

\section{Neurophysiological measurements}

Nerve conduction velocities (NCV) and amplitudes measured 4 months postexposure are shown in tables 3 and 4 , along with the corresponding measurements of the reference group. For the ulnar nerve, the mean sensory NCV was significantly lower (52.3 versus $58.9 \mathrm{~m} / \mathrm{s}, \mathrm{P}=0.001$ ) and the mean motor distal delay was significantly prolonged (3.1 versus $2.5 \mathrm{~ms}, \mathrm{P}=0.001$ ) in the exposed workers when compared with the corresponding values of the referents. For the amplitudes, the standard deviations of the measurements were large. The mean sensory amplitude of the median nerve was significantly lower (table 4), while the median nerve motor amplitude was significantly higher among the exposed participants than among the referents.

When the NCV values and amplitudes from 4 months postexposure were compared with the corresponding measurements 1 year later (tables 5 and 6, respectively), there was statistically significant improvement in the mean sensory NCV of the ulnar nerve, from 52.9 to $57.5 \mathrm{~m} / \mathrm{s}$ $(\mathrm{P}=0.01)$, and also in the mean motor distal delay of the same nerve. The motor amplitude was significantly reduced, while the mean sensory amplitude of the median nerve was improved $(\mathrm{P}=0.01)$. In the sural nerve, there was a significant reduction of the mean sensory amplitude $(\mathrm{P}=0.02)$ and a slight reduction of the mean sensory $\operatorname{NCV}(\mathrm{P}=0.05)$. There was also a slightly prolonged mean F-latency for the tibial nerve $(\mathrm{P}=0.01)$.

When the exposed workers were divided according to length of exposure (less or greater than 18 months of injection work), an exposure-related trend was observed, with significant differences between the longest exposed group and the referents both for sensory NCV (51.8 versus $58.9 \mathrm{~m} / \mathrm{s}$ ) and distal delay in the ulnar nerve (3.14 versus $2.55 \mathrm{~ms}) 4$ months postexposure. One year later, the measurements of the exposed group approached the reference values, but only partially for distal delay.

To assess the possible exposure-related reversibility of NCV further, we examined the correlation between indices of acrylamide exposure and the improvement (as percentage) in neurographic measurements between 4 and 16 months postexposure (table 7). Statistically significant correlation coefficients (range 0.45-0.54) were observed between the percentage of improvement in both the motor and sensory NCV of the arms and the tunnel time and exposure time index, indicating that those with the highest exposures had the largest improvement in NCV from 
Table 3. Nerve conduction velocities (NCV) of the 24 acrylamide-exposed workers 4 months after the cessation of the exposure in comparison with that of the 50 referents.

\begin{tabular}{|c|c|c|c|c|c|c|c|c|c|c|c|c|c|}
\hline \multirow[t]{3}{*}{ Group } & \multicolumn{4}{|c|}{ Median nerve } & \multicolumn{4}{|c|}{ Ulnar nerve } & \multirow{2}{*}{$\frac{\text { Sural nerve }}{\text { Sensory }}$} & \multicolumn{2}{|c|}{ Tibial nerve } & \multicolumn{2}{|c|}{ Peroneal nerve } \\
\hline & $\begin{array}{l}\text { Motor } \\
\text { NCV } \\
(\mathrm{m} / \mathrm{s})\end{array}$ & $\begin{array}{c}\text { Sensory } \\
\text { NCV } \\
(\mathrm{m} / \mathrm{s})\end{array}$ & $\begin{array}{l}\text { Distal } \\
\text { delay } \\
(\mathrm{ms})\end{array}$ & $\begin{array}{c}\text { F- } \\
\text { response } \\
(\mathrm{ms})\end{array}$ & $\begin{array}{l}\text { Motor } \\
\text { NCV } \\
(\mathrm{m} / \mathrm{s})\end{array}$ & $\begin{array}{c}\text { Sensory } \\
\text { NCV } \\
(\mathrm{m} / \mathrm{s})\end{array}$ & $\begin{array}{l}\text { Distal } \\
\text { delay } \\
(\mathrm{ms})\end{array}$ & $\begin{array}{c}\text { F- } \\
\text { response } \\
\text { (ms) }\end{array}$ & & $\begin{array}{l}\text { Motor } \\
\text { NCV } \\
(\mathrm{m} / \mathrm{s})\end{array}$ & $\begin{array}{c}\text { F- } \\
\text { response } \\
\text { (ms) }\end{array}$ & $\begin{array}{l}\text { Motor } \\
\text { NCV } \\
(\mathrm{m} / \mathrm{s})\end{array}$ & $\begin{array}{c}\mathrm{F}- \\
\text { response } \\
(\mathrm{ms})\end{array}$ \\
\hline & Mean SD & Mean SD & Mean SD & Mean SD & Mean SD & Mean SD & Mean SD & Mean SD I & Mean SD N & Mean SD & Mean SD & Mean SD & Mean SD \\
\hline
\end{tabular}

$\begin{array}{llllllllllllllllllllllllllllll}\text { Exposed } & 54.7 & 4.1 & 53.5 & 5.5 & 3.8 & 0.8 & 24.5 & 1.8 & 57.9 & 6.1 & 52.3^{\text {a }} & 5.8 & 3.1 & 0.7 & 26.0 & 2.2 & 47.0^{\mathrm{b}} & 6.7 & 44.2 & 4.3 & 50.3^{\mathrm{a}} & 6.2 & 46.5 & 4.7 & 48.1^{\mathrm{a}} & 5.3\end{array}$

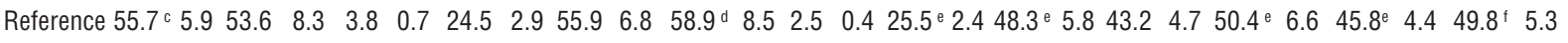

\begin{tabular}{lllllllllllllll} 
P-value & 0.46 & 0.94 & 0.91 & 0.98 & 0.23 & 0.001 & 0.001 & 0.42 & 0.41 & 0.37 & 0.97 & 0.50 & 0.21 \\
\hline
\end{tabular}

a $\mathrm{N}=23 . \quad{ }^{\mathrm{b}} \mathrm{N}=21 . \quad \mathrm{c} \mathrm{N}=48 . \quad \mathrm{d} \mathrm{N}=46 . \quad$ e $\mathrm{N}=49 . \quad{ }^{\dagger} \mathrm{N}=44$.

Table 4. Motor and sensory amplitudes in selected nerves of 24 acrylamide-exposed workers 4 months after the cessation of the exposure in comparison to those of the 50 referents.

\begin{tabular}{|c|c|c|c|c|c|c|c|c|c|c|c|c|c|c|}
\hline \multirow[t]{4}{*}{ Group } & \multicolumn{14}{|c|}{ Amplitudes } \\
\hline & \multicolumn{4}{|c|}{ Median nerve } & \multicolumn{4}{|c|}{ Ulnar nerve } & \multirow{2}{*}{\multicolumn{2}{|c|}{$\begin{array}{l}\text { Sural nerve } \\
\text { Sensory }(\mu \mathrm{V})\end{array}$}} & \multirow{2}{*}{\multicolumn{2}{|c|}{$\begin{array}{l}\text { Tibial nerve } \\
\text { Motor (mV) }\end{array}$}} & \multirow{2}{*}{\multicolumn{2}{|c|}{$\begin{array}{c}\text { Peroneal nerve } \\
\text { Motor (mV) }\end{array}$}} \\
\hline & \multicolumn{2}{|c|}{ Motor (mV) } & \multicolumn{2}{|c|}{ Sensory $(\mu \mathrm{V})$} & \multicolumn{2}{|c|}{ Motor (mV) } & \multicolumn{2}{|c|}{ Sensory $(\mu \mathrm{V})$} & & & & & & \\
\hline & Mean & SD & Mean & SD & Mean & SD & Mean & SD & Mean & SD & Mean & SD & Mean & SD \\
\hline Exposed & 9.1 & 3.0 & 16.9 & 11.5 & 7.9 & 3.7 & $9.7^{\mathrm{a}}$ & 6.9 & $12.0^{\mathrm{b}}$ & 9.6 & 4.3 & 2.6 & 3.5 & 1.7 \\
\hline Reference & 6.7 & 3.2 & 31.2 & 36.3 & 6.5 & 2.0 & $13.1^{c}$ & 11.7 & $8.1^{\mathrm{a}}$ & 5.7 & 4.4 & 2.2 & 3.6 & 2.1 \\
\hline P-value & \multicolumn{2}{|c|}{0.004} & \multicolumn{2}{|c|}{0.01} & \multicolumn{2}{|c|}{0.09} & \multicolumn{2}{|c|}{0.19} & \multicolumn{2}{|c|}{0.07} & \multicolumn{2}{|c|}{0.83} & \multicolumn{2}{|c|}{0.98} \\
\hline
\end{tabular}

a Not elicited in one subject.

${ }^{b}$ Not elicited in three subjects.

c Not elicited in two subjects.

Table 5. Comparison of the mean nerve conduction velocities (NCV) 4 and 16 months after the acrylamide exposure of the 24 tunnel workers.

\begin{tabular}{|c|c|c|c|c|c|c|c|c|c|c|c|c|c|c|c|c|c|c|c|c|}
\hline \multirow{3}{*}{$\begin{array}{l}\text { Time of } \\
\text { measure- } \\
\text { ment }\end{array}$} & \multicolumn{5}{|c|}{ Median nerve } & \multicolumn{6}{|c|}{ Ulnar nerve } & \multirow{2}{*}{\multicolumn{2}{|c|}{$\begin{array}{c}\text { Sural nerve } \\
\text { Sensory } \\
N C V \\
(\mathrm{~m} / \mathrm{s}) \\
(\mathrm{N}=20)\end{array}$}} & \multicolumn{4}{|c|}{ Tibial nerve } & \multicolumn{3}{|c|}{ Peroneal nerve } \\
\hline & $\begin{array}{l}\text { Motor } \\
\text { NCV } \\
(\mathrm{m} / \mathrm{s})\end{array}$ & & $\begin{array}{l}\text { insory } \\
\text { NCV } \\
\text { m/s) } \\
\text { d=23) }\end{array}$ & $\begin{array}{l}\text { Distal } \\
\text { delay } \\
\text { (ms) }\end{array}$ & $\begin{array}{c}\text { F- } \\
\text { response } \\
\text { (ms) }\end{array}$ & $\begin{array}{l}\text { Motor } \\
\text { NCV } \\
(\mathrm{m} / \mathrm{s})\end{array}$ & $\begin{array}{c}\text { Senss } \\
N C l \\
(\mathrm{~m} / \mathrm{s} \\
(\mathrm{N}=2\end{array}$ & $\begin{array}{l}\text { sory } \\
\text { /s) } \\
22)\end{array}$ & $\begin{array}{l}\text { Dista } \\
\text { dela) } \\
\text { (ms) }\end{array}$ & & $\begin{array}{r}\text { F- } \\
\text { respon } \\
(\mathrm{ms})\end{array}$ & & & & $\begin{array}{l}\text { lotor } \\
\text { NCV } \\
\mathrm{m} / \mathrm{s} \text { ) }\end{array}$ & $\begin{array}{r}\text { F- } \\
\text { respor } \\
\text { (ms }\end{array}$ & $\begin{array}{l}\text { - } \\
\text { onse } \\
\text { s) }\end{array}$ & $\begin{array}{l}\text { Motor } \\
\text { NCV } \\
(\mathrm{m} / \mathrm{s})\end{array}$ & $\begin{array}{r}F \\
\text { respc } \\
(m\end{array}$ & $\begin{array}{l}\text { F- } \\
\text { onse } \\
\text { ns) }\end{array}$ \\
\hline & Mean SD & Mea & an SD & Mean SD & Mean SD & Mean SD & Mean & SD M & Mean & SD N & Mean $\varsigma$ & SD M & Mean SD & Mean & an SD & Mean & SD & Mean SD & Mean & רD \\
\hline $\begin{array}{l}4 \text { months } \\
\text { post-. } \\
\text { exposure }\end{array}$ & 54.74 .1 & 53.4 & 45.5 & $\begin{array}{ll}3.8 & 0.8\end{array}$ & 24.51 .8 & $57.9 \quad 6.1$ & 52.9 & 5.3 & 3.10 & 0.72 & 26.02 & 2.247 & $47.6 \quad 6.4$ & 444.2 & 24.3 & 50.3 & 6.2 & $46.5 \quad 4.7$ & 48.1 & 5.3 \\
\hline $\begin{array}{l}16 \text { months } \\
\text { post- } \\
\text { exposure }\end{array}$ & is 54.56 .3 & 52.5 & 57.0 & $3.7 \quad 0.6$ & 25.02 .0 & 58.17 .7 & 57.5 & 7.4 & $2.7 \mathrm{c}$ & 0.52 & 26.52 & 2.045 & $45.1 \quad 3.5$ & 545.5 & 55.1 & 51.9 & 5.7 & $\begin{array}{ll}46.4 & 4.8\end{array}$ & 48.3 & 6.8 \\
\hline P-value a & 0.92 & & 0.47 & 0.11 & 0.10 & 0.90 & 0.02 & 02 & 0.00 & & 0.19 & & 0.05 & & .32 & 0.0 & 01 & 0.91 & 0.7 & .75 \\
\hline
\end{tabular}

a Paired sample, t-test; paired differences.

Table 6. Comparison of the mean sensory and motor amplitudes of the 24 acrylamide-exposed workers 4 and 16 months postexposure.

\begin{tabular}{|c|c|c|c|c|c|c|c|c|c|c|c|c|c|c|}
\hline \multirow[t]{3}{*}{ Time of measurement } & \multicolumn{4}{|c|}{ Median nerve } & \multicolumn{4}{|c|}{ Ulnar nerve } & \multirow{2}{*}{\multicolumn{2}{|c|}{$\begin{array}{c}\text { Sural nerve } \\
\text { Sensory }(\mu \mathrm{V})\end{array}$}} & \multirow{2}{*}{\multicolumn{2}{|c|}{$\frac{\text { Tibial nerve }}{\text { Motor (mV) }}$}} & \multirow{2}{*}{\multicolumn{2}{|c|}{$\begin{array}{c}\text { Peroneal nerve } \\
\text { Motor (mV) }\end{array}$}} \\
\hline & \multicolumn{2}{|c|}{ Motor (mV) } & \multicolumn{2}{|c|}{ Sensory $(\mu \mathrm{V})$} & \multicolumn{2}{|c|}{ Motor (mV) } & \multicolumn{2}{|c|}{ Sensory $(\mu \mathrm{V})$} & & & & & & \\
\hline & Mean & SD & Mean & SD & Mean & SD & Mean & SD & Mean & SD & Mean & SD & Mean & SD \\
\hline 4 months postexposure & 9.1 & 3.0 & 16.9 & 11.5 & 7.9 & 3.7 & 9.7 & 6.9 & 12.0 & 9.6 & 4.3 & 2.6 & 3.5 & 1.7 \\
\hline 16 months postexposure & 8.4 & 3.5 & 35.5 & 35.1 & 5.7 & 1.9 & 9.5 & 7.7 & 7.2 & 5.3 & 4.3 & 2.1 & 3.0 & 1.6 \\
\hline P-value & \multicolumn{2}{|c|}{0.36} & \multicolumn{2}{|c|}{0.01} & \multicolumn{2}{|c|}{0.01} & \multicolumn{2}{|c|}{0.94} & \multicolumn{2}{|c|}{0.02} & \multicolumn{2}{|c|}{0.94} & \multicolumn{2}{|c|}{0.15} \\
\hline
\end{tabular}


Table 7. Correlation between the indices of acrylamide exposure and the percentage of improvement in the neurographic measures from 4 to 16 months postexposure. (NCV = nerve conduction velocity)

\begin{tabular}{|c|c|c|c|c|c|c|c|c|c|}
\hline \multirow[t]{2}{*}{ Nerve } & \multirow[t]{2}{*}{$\mathrm{N}^{\mathrm{a}}$} & \multicolumn{2}{|c|}{ Improvement (\%) } & \multicolumn{2}{|c|}{ Tunnel time } & \multicolumn{2}{|c|}{ Exposure time index } & \multicolumn{2}{|c|}{ Intensity index } \\
\hline & & Mean & SD & Correlation & P-value & Correlatio & P-value & Correlatio & P-value \\
\hline \multicolumn{10}{|l|}{ Median } \\
\hline Motor NCV (m/s) & 24 & 0.3 & 14.2 & 0.45 & 0.03 & 0.39 & 0.06 & 0.33 & 0.12 \\
\hline Sensory NCV (m/s) & 23 & -1.5 & 10.4 & 0.49 & 0.02 & 0.54 & 0.01 & 0.08 & 0.73 \\
\hline Distal delay (ms) & 24 & 2.8 & 11.4 & 0.02 & 0.94 & -0.06 & 0.77 & 0.23 & 0.28 \\
\hline F-response (ms) & 24 & -2.1 & 5.8 & 0.22 & 0.30 & 0.53 & 0.01 & 0.16 & 0.46 \\
\hline \multicolumn{10}{|l|}{ Ulnar } \\
\hline Motor NCV (m/s) & 24 & 0.7 & 11.6 & 0.13 & 0.54 & 0.36 & 0.09 & -0.14 & 0.52 \\
\hline Sensory NCV (m/s) & 22 & 9.5 & 15.9 & 0.54 & 0.01 & 0.53 & 0.01 & -0.04 & 0.85 \\
\hline Distal delay (ms) & 24 & 11.7 & 14.7 & 0.03 & 0.90 & -0.06 & 0.77 & -0.13 & 0.54 \\
\hline F-response (ms) & 24 & -2.7 & 9.1 & 0.40 & 0.05 & 0.50 & 0.01 & 0.34 & 0.10 \\
\hline \multicolumn{10}{|l|}{ Sural } \\
\hline Sensory NCV (m/s) & 20 & -4.1 & 9.5 & 0.05 & 0.83 & 0.32 & 0.17 & 0.26 & 0.27 \\
\hline \multicolumn{10}{|l|}{ Tibial } \\
\hline Motor NCV (m/s) & 24 & 3.4 & 13.1 & 0.29 & 0.16 & 0.12 & 0.57 & 0.31 & 0.14 \\
\hline \multicolumn{10}{|l|}{ Peroneal } \\
\hline Motor NCV (m/s) & 24 & 0.1 & 8.8 & 0.06 & 0.77 & 0.19 & 0.37 & 0.22 & 0.30 \\
\hline F-response (ms) & 23 & -0.5 & 9.0 & -0.01 & 0.98 & 0.19 & 0.38 & 0.01 & 0.95 \\
\hline
\end{tabular}

a $\mathrm{N}=$ number of measurements.

b Spearman's rank correlation coefficients.

4 to 16 months postexposure. Correspondingly, the Flatencies in the median and the ulnar nerve showed significant correlations with the exposure time index, indicating exposure-related improvement. A significant correlation between improvement in the motor amplitude of the median nerve and tunnel time and between improvement in the motor amplitude of the tibial nerve and the intensity index was observed (correlation coefficients $0.47, \mathrm{P}<0.05$, and $0.41, \mathrm{P}<0.05$, respectively) (table not shown).

\section{Discussion}

Previous reports on acrylamide effects on humans have mainly been related to the primary production of acrylamide from acrylonitrile or to the polymerization of acrylamide to polyacrylamide (4). Later, similar effects were reported for tunnel workers in relation to grouting operations (10-13). In most cases, the symptoms and signs have been reversible, with full restitution after 212 months after the cessation of exposure $(4,14,15)$. However, in severe intoxications, symptoms have persisted for several years $(12,16)$. The grouts used by the workers in these studies have mainly been based on pure acrylamide or, as in one study, on $\mathrm{N}$-methylacrylamide and methylen-bis-acrylamide (11). Thus the Swedish study (1) and our study are, to our knowledge, the first to report neurological effects on workers exposed to grouts based on NMA.
Animal studies and previous clinical studies of acrylamide neurotoxicity have shown an axonal lesion of the distal "dying back" type, which is typical for several neurotoxic substances affecting the peripheral nerves $(15,17)$. An axonal lesion is characterized by the reduction of motor or sensory amplitudes. The mechanism causing this effect is not completely understood, but a direct neurotoxic effect at the nerve endings where the "blood-nerve barrier" is weak, or a toxic effect on neuronal metabolism and protein synthesis, has been suggested as a possible explanation. Previous studies have indicated that acrylamide affects both motor and sensory nerve fibers, where long, sensory fibers seem to be the most vulnerable (17).

Most of the neurographic measurements of our study showed no significant differences in the mean results either in comparisons with the reference group or over time. There was, however, a slight, but significant reversible effect on the mean sensory nerve conduction velocity and motor distal delay in the ulnar nerve and also a reduction of the mean sensory nerve conduction velocity and sensory amplitude in the sural nerve on examination after 16 months. With the use of exposure variables, exposure-related improvements after 16 months were observed, both for the median nerve (motor and sensory NCV and F-response) and ulnar nerve (sensory NCV, F-response), indicating a reversible neurotoxic effect, although small and possibly subclinical.

The findings in the upper limbs showed reductions in conduction velocities, which indicate a toxic effect 
on myelin, with only a slightly significant reduction in the sensory amplitude of the median nerve. This finding is in contrast with the results of previous studies (1820) on acrylamide exposure, which have rather consistently shown reduced amplitudes as a sign of axonal degeneration. When the large random variation in the amplitude measurements is considered, the intermittent NMA-acrylamide exposure over a relatively long time (2 years) may not have been sufficient for the detection of any effect on the amplitudes in such a small group of workers 4 months or more after the cessation of exposure.

The early reversible changes were found in the upper, but not the lower, extremities, and this finding is uncharacteristic of polyneuropathies. One explanation may be that the effect could be have been caused by direct contact after diffusion through the skin of the hands. This diffusion may possibly have caused a direct, myelinolytic effect on distal nerve fibers that differed from the toxic effect on neuron metabolism causing axonal damage found in other studies of acrylamide. There was, however, an apparent reduction in the mean sensory nerve conduction and mean sensory amplitude of the sural nerve from 4 to 16 months postexposure. The type and localization of this lesion is more in accordance with the findings of previous reports on acrylamide effects. This delayed finding, if not a random error, could indicate that the changes may have taken a longer time to develop and had persisted for a longer time than what one would have expected.

No measurements of acrylamide or NMA in the work atmosphere were performed in our study. How relevant such information would have been, however, is questionable, as it is believed that the main uptake of acrylamide during grouting operations is through the skin, and not through inhalation (1). The concentrations of acrylamide and NMA in tunnel drain water immediately after the injection was stopped could provide a crude indicator of recent exposure, not only during injection work, but also during other worktasks. The observation of very high concentrations of acrylamide $(90.6 \mathrm{mg} / \mathrm{l})$ in water dripping from bore holes in January 1998 indicates the possibility of some exposure also after the injection period. However, it is believed that the exposure was radically reduced after the end of the injection work.

Measurement of hemoglobin adducts from acrylamide in blood would give a valid and sensitive estimate of the average exposure during the preceding months $(9,21,22)$. However, for conclusions to be drawn about the occupational exposure from relatively low adduct levels, a careful examination of adduct levels, with regard to the contribution from other factors as well as the decline of adduct levels after the cessation of exposure, has to be performed.
The levels of adducts due to occupational exposure to acrylamide are added to a background adduct level (20-70 pmol/g Hb for nonsmokers) (1, 9). This background level is mainly associated with dietary habits with the formation of acrylamide during the cooking of foodstuffs, particularly of carbohydrate-rich foods (23) and, possibly, a contribution from endogenously formed acrylamide. Due to the occurrence of acrylamide in tobacco smoke, smokers exhibit an increase in the background level (about $6 \mathrm{pmol} / \mathrm{g} \mathrm{Hb}$ per cigarette/day) (9).

The significant increase in the acrylamide adduct level (by about $50 \mathrm{pmol} / \mathrm{g} \mathrm{Hb}$ ) among the nonsmoking workers was assumed to signify that exposure occurred during work. This observed increase in acrylamide adduct levels among nonsmoking workers may have originated from a recent low occupational exposure or from an earlier high exposure. Permanent or intermittent exposure to compounds that form adducts to hemoglobin leads to a steadystate adduct level after about 4 months (which is the life span, $t_{\text {er }}$, of erythrocytes and hemoglobin adducts). The adduct levels decay after discontinuation of exposure and reach zero after a life span of $t_{\text {er }} \approx 126$ days. Thus adduct levels measured at different times after the cessation of an exposure period might be "corrected backwards" to the true value on the day of exposure cessation (22). This possibility implies that, after a certain time after exposure, the adduct contribution from the occupational exposure has decreased, while adducts from background sources such as smoking and diet remain at about the same level. The results indicate that, during injection work, some of the examined workers may have had adduct levels reaching the range of $1 \mathrm{nmol} / \mathrm{g}$ globin, considering that the first blood samples were collected about 2 months after the cessation of injection work, when the adduct level has declined to about $30 \%$ of the maximum level.

The observations that only two participants had clearly elevated adduct levels and that the collective increase in the adduct level was low (about $50 \mathrm{pmol} / \mathrm{g} \mathrm{Hb}$ ) strengthen the suggestion that the tunnel drain water was not an important source of exposure after the injection work ended.

It is of interest to compare the exposure conditions in the Swedish and Norwegian tunnel projects. In Sweden, about 1500 tonnes of the NMA grout were used during 6-8 weeks, while in the Norwegian study, 340 tonnes were used during a 2-year period. Of the 210 Swedish workers, 36 had hemoglobin adduct values of $0.30-1.00 \mathrm{nmol} /$ $\mathrm{g} \mathrm{Hb}, 38 \mathrm{had}$ values of $>1.00 \mathrm{nmol} / \mathrm{g} \mathrm{Hb}$, and the highest value measured was $17.7 \mathrm{nmol} / \mathrm{g} \mathrm{Hb}$ (1). Although their blood samples were taken 1 to 5 weeks after the cessation of exposure, these results indicate that the exposure levels during the injection work were higher in the Swedish study.

A no-effect threshold level for acrylamide or acrylamide + NMA exposure has been estimated to correspond 
to an adduct level of about $300 \mathrm{pmol} / \mathrm{g} \mathrm{Hb}$ for light, mostly reversible nervous symptoms in humans (1, 24 with data from 25). In agreement with this estimation, slight symptoms of neurotoxic effects were observed in our study, a fact that underlines the earlier finding that the no-effect threshold for slight neurotoxic symptoms in humans may be much lower than the threshold value estimated from animal experiments. The value 300 $\mathrm{pmol} / \mathrm{g} \mathrm{Hb}$ from continuous or intermittent exposure over the life span of erythrocytes corresponds to an uptake of about $10 \mu \mathrm{g} / \mathrm{kg}$ per day (24) if the parameter values of Calleman (26) are used. From animal experiments a no-effect threshold corresponding to $500 \mu \mathrm{g} / \mathrm{kg}$ per day $(27,28)$ has been estimated.

In view of the lack of reliable quantitative exposure data, we aimed at optimizing the use of qualitative exposure data by introducing a set of surrogate variables. When comparing the different approaches, the information on the time of the injection work (in months) was a good predictor of the NCV reversibility outcomes, only marginally improved when the different time periods were given weights according to the amount of NMA grout used (29). Due to the high correlation between months of injection and the exposure time index, we chose to present the latter. Some exposure-related improvements occurred even without any improvement in the mean values (table 7), indicating that those with the highest or longest exposures had the largest improvements. The improvements were not correlated to age. The intensity index, based upon questionnaire data on the frequency of the different worktasks, did not predict reversibility.

NMA-based grout was used because of its low toxicity when compared with that of acrylamide. Thus, in animal experiments, the neurotoxic potential of NMA has been reported to be $20-30 \%$ of that of acrylamide (3). An important question is, therefore, to what degree the workers were also exposed to acrylamide momomer in addition to the NMA exposure during the grouting operations. The average content of acrylamide in solution 1 was $4-5 \%$. The actual content of acrylamide in the NMA grout during the tunnel work is very unclear, however, partly because of protracted polymerization of the grout in the cold tunnel and partly because NMA may be hydrolyzed back to acrylamide. Under favorable conditions, the polymerization should be completed within a few hours. Polymerization experiments have shown delayed polymerization, up to 1 week after the mixing of the components (30). Measurements after the cessation of the injection work indicated a 2:1 ratio of the concentrations of NMA to acrylamide in the tunnel water, compared with 5-10:1 in the grout (5). Together with the observation of very high acrylamide concentrations $(90.6 \mathrm{mg} / \mathrm{l})$ in the water from drill holes in the tunnel as late as 5 months after the injection work, the exposure to the mixed, but not yet polymerized, product may have led to exposure to higher concentrations of acrylamide among the workers than previously believed when the NMA grout was introduced.

With regard to validity, this study was performed as two cross-sectional examinations of the 24 exposed tunnel workers who were judged to be among the most highly exposed of 73 eligible tunnel workers who participated in the occupational health survey of the construction company. This participation was complete for all relevantly exposed subjects, independent of symptom status. However, the selection of the 24 subjects for the follow-up study was performed after the occupational health survey was initiated and is thus particularly vulnerable to outcome-dependent selection. The thorough selection procedure makes us fairly convinced that the selection of the participants was based on exposure criteria exclusively, and not on subjective symptoms or other effects.

Tunnel workers are exposed to a variety of exposure factors, and this exposure could, in part, have confounded the examined effects. Thus exposure to other neurotoxic agents, such as organic solvents, lead or other metals, together with vibration exposure could have influenced the observed effects. In addition, exposure to other factors related to life-style, such as smoking, might also have been different from that of the general population (31). In our study, we used an external reference group of tunnel or construction workers and performed within-group and within-person comparisons among the exposed subjects at two different points in time. The distribution of age, other occupational exposure factors, and life-style (smoking, alcohol) were comparable between the groups (table 1). However, although the two groups had experience that was comparable with that of the tunnel and construction workers (19.3 and 20.4 years, respectively), the index group had been involved in direct tunnel work for a much longer time than the reference group (14.8 versus 3.8 years). Overall, we believe that the choice of our reference group ensured the necessary comparability between the groups. In the reversibility studies, the use of intraindividual comparisons excluded between-group confounding.

In conclusion, the results of our study indicate slight axonal and demyelinating effects on sensory and motor fibers in the peripheral nerves of the upper extremities in relation with exposure to NMA and acrylamide among 24 tunnel workers during grouting operations in tunnel work. Uptake through the skin after dermal exposure seemed to be the most likely route of exposure. Apart from a possible late effect on sensory fibers in the sural nerve, the effects seemed to be reversible, with normalization of symptoms and neurographic measurements 16 months after the cessation of the grouting work. The results from this small study need to be confirmed by other studies. 


\section{Acknowledgments}

This study was supported by the Confederation of Norwegian Business and Industry Work Environment Fund, Scandinavian Rock Group ANS (SRG), Gardermobanen AS, and Rhodia PPMC.

We thank Ingrid Botnen for her technical assistance and Patricia Flor for her linguistic assistance.

\section{References}

1. Hagmar L, Törnqvist M, Nordander C, Rosén I, Bruze M, Kautiainen A, et al. Health effects of occupational exposure to acrylamide using hemoglobin adducts as biomarkers of internal dose. Scand J Work Environ Health 2001;27:21926.

2. Kjuus H. Acrylamide in tunnel construction-new (or old) lessons to be learned? [editorial]. Scand J Work Environ Health 2001;27(4):217-18.

3. International Agency for Research on Cancer (IARC). Some industrial chemicals. Lyon: IARC; 1994. p 435-53. Monographs on the evaluation for carcinogenic risk of chemicals to humans, vol 60 .

4. World Health Organization (WHO). Acrylamide. Geneva: WHO; 1985. Environmental health criteria 49.

5. Sverdrup L, Vik EA, Weideborg M, Kelley A, Fürst C, Källqvist T, et al. Utslipp knyttet til bruk av kjemiske injeksjonsmidler i Romeriksporten: sluttrapport [Effluents related to use of chemical injection agents in Romeriksporten: final report]. Oslo: Aquateam-Norsk vannteknologisk senter A/ S; 1999. Report 99-010.

6. Mowrer J, Törnqvist M, Jensen S, Ehrenberg L. Modified Edman degradation applied to hemoglobin for monitoring occupational exposure to alkylating agents. Toxicol Environ Chem 1986;11:215-31.

7. Törnqvist M, Mowrer J, Jensen S, Ehrenberg L. Monitoring of environmental cancer initiators through hemoglobin adducts by the modified Edman method. Anal Biochem 1986;154:255-66.

8. Bergmark E, Calleman CJ, He F, Costa LG. Determination of hemoglobin adducts in humans occupationally exposed to acrylamide. Toxicol Appl Pharmacol 1993;120;45-54.

9. Bergmark, E. Hemoglobin adducts of acrylamide and acrylonitrile in laboratory workers, smokers, and nonsmokers. Chem Res Toxicol 1997;10:78-84.

10. Graveleau J, Loirat P, Nusinovici V. Polynévrite par l'acrylamide [Polyneuropathy caused by acrylamide]. Rev Neurol 1970;123:62-5.

11. Kesson CM, Baird AW, Lawson DH. Acrylamide poisoning. Postgrad Med J 1977;53:16-7.

12. Mapp C, Mazzotta M, Bartolucci GB, Fabbri L. La neuropatia da acrilamide: prime osservazioni in Italia [Neuropathy due to acrylamide: first observations in Italy]. Med Lav 1977;68(1):1-12.

13. Garland TO, Patterson MWH. Six cases of acrylamide poisoning. BMJ 1967;4:134-38.

14. Tilson HA. The neurotoxicity of acrylamide: an overview. Neurobehavioral Toxicol Teratol 1981;3:445-61.

15. Myers JE, Macun I. Acrylamide neuropathy in a South Afri- can factory: an epidemiologic investigation. Am J Ind Med 1991;19:487-93.

16. Smith EA, Oehme FW. Acrylamide and polyacrylamide: a review of production, use, environmental fate and neurotoxicity. Rev Environ Health 1991;9:215-28.

17. Fullerton P. Electrophysiological and histological observations on peripheral nerves in acrylamide poisoning in man. $\mathrm{J}$ Neurol Neurosurg Psychiatr 1969;32:186-92.

18. He F, Zhang S, Wang H, Li G, Zhang Z, Li F. Neurological and electroneuromyographic assessment of the adverse effects of acrylamide on occupationally exposed workers. Scand J Work Environ Health 1989;15:125-9.

19. Takahashi M, Ohara T, Hashimoto K. Electrophysiological study of nerve injuries in workers handling acrylamide. Int Arch Arbeitsmed 1971;28:1-11.

20. Spencer PS, Schaumburg HH. Nervous system degeneration produced by acrylamide monomer. Environ Health Perspect 1975;11:129-33.

21. Törnqvist M, Fred C, Haglund J, Helleberg H, Paulsson B, Rydberg P. Protein adducts: quantitative and qualitative aspects of their formation, analysis and applications. J Chromatogr 2002;778:279-308.

22. Granath F, Ehrenberg L, Törnqvist M. Degree of alkylation of macromolecules in vivo from variable exposure. Mutat Res 1992;284:297-306.

23. Tareke E, Rydberg P, Karlsson P, Eriksson S, Törnqvist M. Acrylamide: a carcinogenic compound formed during heating of foodstuffs. J Agric Food Chem 2002;50:4998-5006.

24. Törnqvist M, Bergmark E, Ehrenberg L, Granath F. Riskbedömning av akrylamid [Risk assessment of acrylamide] . Stockholm: Kemikalieinspektionen; 1998. p 5-24.PM KEMI nr 7/98

25. Calleman C-J, Wu Y, He F, Tian G, Bergmark E, Zhang S, et al. Relationships between biomarkers of exposure and neurological effects in a group of workers exposed to acrylamide. Toxicol Appl Pharmacol 1994;126:361-71.

26. Calleman C-J. The metabolism and pharmacokinetics of acrylamide: implications for mechanisms of toxicity and human risk estimation. Drug Metab Rev 1996;28:527-90.

27. Johnson KA, Gorzinski SJ, Bodner KM, Campbell RA, Wolf $\mathrm{CH}$, Friedman MA, et al. Chronic toxicity and oncogenicity study on acrylamide incorporated in the drinking water of Fisher 344 rats. Toxicol Appl Pharmacol 1986;85:154-68.

28. World Health Organization (WHO). Health implications of acrylamide in food: report of a joint FAO/WHO consultation. Geneva: Department of Protection of the Human Environment, WHO; 2002.

29. Kjuus H, Goffeng LO, Skaug V, Heier M. Comparison of qualitative indices of exposure to acrylamide-containing grouting agents during tunnel work. In: Exposure assessment in epidemiology and practice, Gøteborg 11-13 June 2001. Stockholm: National Institute for Working Life, 2001. p 11415. Arbete och Hälsa 2001;10.

30. Ødegård KE. Ringstad O. Sammendrag av aktiviteter utført av SINTEF Kjemi i forbindelse med arbeidet i Romeriksporten [Summary of activities of SINTEF Kjemi related to work in Romeriksporten]. Trondheim: SINTEF Kjemi; 1999. Report STF66 A99513.

31. Ulvestad B, Bakke B, Melbostad E, Fuglerud P, Kongerud J, Lund MB. Increased risk of obstructive pulmonary disease in tunnel workers. Thorax 2000;55:277-82.

Received for publication: 24 February 2003 